Article

\title{
Soil Erosion and Forests Biomass as Energy Resource in the Basin of the Oka River in Biscay, Northern Spain
}

\author{
Esperanza Mateos $^{1, *}$, José Miguel Edeso ${ }^{2}$ and Leyre Ormaetxea ${ }^{3}$ \\ 1 Department of Chemical and Environmental Engineering, University of the Basque Country UPV/EHU, \\ Rafael Moreno 'Pitxitxi', n 3, 48013 Bilbao, Spain \\ 2 Department of Mining, Escuela Técnica de Ingenieros de Minas, University of the Basque Country \\ UPV/EHU, E-01006 Vitoria, Spain; josemiguel.edeso@ehu.eus \\ 3 Department of Mathematics, Faculty of Science and Technology, University of the Basque Country \\ UPV/EHU, Barrio Sarriena s/n, 48940 Leioa, Spain; leyre.ormaetxea@ehu.eus \\ * Correspondence: esperanza.mateos@ehu.eus; Tel.: +34-946-10-43-43; Fax: +34-946-10-43-00
}

Academic Editor: Raffaele Spinelli

Received: 10 April 2017; Accepted: 12 July 2017; Published: 19 July 2017

\begin{abstract}
The aim of this work has been the development of a methodology for the evaluation of residual forest biomass in Biscay, a province in northern Spain. The study area is located in the Oka river basin, an area of great ecological value qualified by UNESCO (United Nations Educational Scientific and Cultural Organization) in 1984 as a Biosphere Reserve. The project tries to determine the potential, available and usable as energy resource, residual forests biomass, after the treatments of forest species in the area. Soil erosion was modeled using the USLE (Universal Soil Loss Equation) and MUSLE (Modified USLE) methods by estimating rainfall erosivity factor (R), the soil erodibility factor $(\mathrm{K})$, the topographic factors ( $\mathrm{L}$ and $\mathrm{S})$, cropping factor $(\mathrm{C})$, and the conservation practice factor (P). By means of these models, it will be possible to determine the current soil erosion rate and its potential evolution due to different forest treatments. Soil erodibility, slope of the terrain and the loss of SOC (Soil Organic Carbon) were the restrictive indicators for the bioenergy use of forest biomass, taking into account principles of sustainability. The amount of residual forestry biomass useable for energy purposes has been estimated at $4858.23 \mathrm{Mg}$ year $^{-1}$.
\end{abstract}

Keywords: soil erosion; GIS (Geographic Information System); forest residues; energy valuation; harvesting management

\section{Introduction}

Forest biomass plays an important role in the overall carbon cycle. This is due, among other reasons, to the contribution it makes to fixing atmospheric carbon and, as a consequence, bringing about a reduction in the greenhouse effect. The Kyoto protocol officially recognised the role of forests as carbon sinks in the mitigation of global climate change factors, basically by reducing the atmospheric concentrations of $\mathrm{CO}_{2}[1,2]$. Forestry activities generate significant quantities of wastes and by-products that are suitable for diverse energy purposes. The most viable alternatives for energy use from forest biomass residues in the area of study are the production of solid bio-fuel and electricity generation, especially in cogeneration plants. The use of forest biomass as an energy source helps to reach the compromises acquired by the European Union in the Kyoto protocol by 2020, 20\% of all energy consumption must come from renewable sources. In Spain, the 2011-2020 Renewable Energy Plan set the target of $20 \%$ of total primary energy needs to be met by renewable sources and about $10 \%$ of these by bioenergy [3]. The use of such residual biomass has become crucial for several reasons. 
Firstly, the combustion of biomass plays a virtually neutral role in the carbon cycle and produces minimum emissions of $\mathrm{SO}_{2}$, particles and $\mathrm{NO}_{x}$. Moreover, due to the absence of chlorine compounds, the formation of dioxins is avoided. Secondly, its removal is the most effective way to prevent forest fires and plagues of insects, and, finally, it favours employment and profitability of forestry activities. These advantages make biomass a potential source of employment for the future, converting it into an element of great importance for regional stability, especially in rural areas [4]. Nevertheless, in order for biomass to be considered a true renewable resource, the speed with which it is used must not be greater than the speed with which it is regenerated as a resource [5]. Sustainable forestry management seeks to strike a balance between present and future needs, involving environmental, social and socio-economic factors [6]. The study of the influence of forestry biomass on soil quality is fundamental in order to predict the evolution of forests and to develop adequate management strategies.

The bibliography contains a number of different investigations into the effect of intensive forestry practices on the productivity of forestry species. Managed forests generally contain much less biomass compared to unmanaged natural forests $[7,8]$. Other researchers analyze the influence of forestry management practices on soil quality and carbon retention in pine plantations. Management practices differ considerably with respect to impacts on carbon sequestration in forests $[9,10]$.

In recent decades and with the aim of satisfying industrial needs, the forestry sector of the study area (Figure 1b) has increased the surface area of plantations of rapid-growth species, basically P. radiata D. Don and Eucalyptus globulus Labill. The latter plays a fundamental role in supplying the cellulose and paper industry.

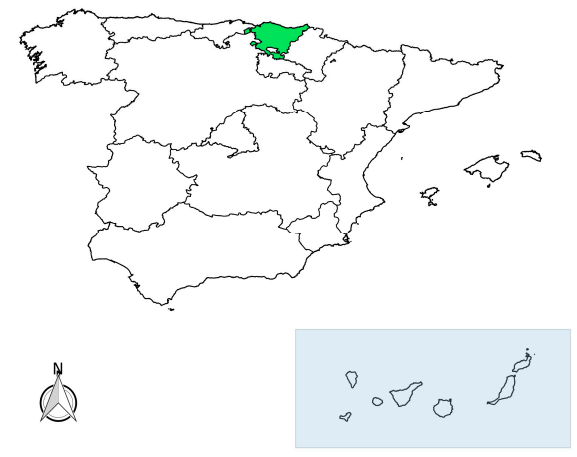

(a)

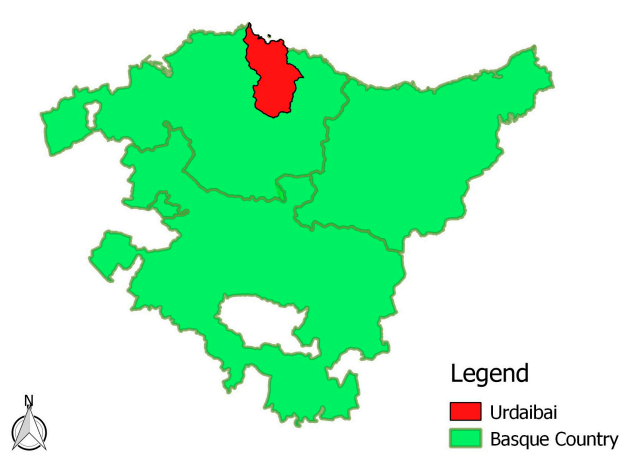

(b)

Figure 1. The landscape of Urdaibai. (a) Spain; (b) Urdaibai: Basque Country.

It is therefore necessary to develop a methodology to evaluate the potential and useable residual forestry biomass for energy production in order to be able to set up installations to use this fuel for energy purposes in the most suitable locations. Until now, the lack of a specific methodology to evaluate the precise amount of residual forestry waste produced by forestry activities has avoided an adequate use of these products for energy purposes. However, a number studies in different parts of Europe and the United States have determined the potential of the existing residual biomass for energy valuation [11,12]. However, few surveys assess the amount of useable forestry biomass taking soil loss into account. Soil quality is considered a key element os sustainable land management. Soil erosion is a major environmental problem in worldwide. Rainfall intensity, vegetation, soil, topography and geology and human beings are usually the main causes of soil erosion [13].

One of the main hindrances to biomass energy management is the difficulty involved in ensuring a steady supply for heat/electricity generating plants. As a result, the amount of biomass and the potential influence on soil loss from its use are essential factors required to quantify if sustainable biomass energy and other products are to be developed. The objectives of this study were as follows: 
1. Validate the soil map of the Oka River Basin obtained in the Third National Forestry Inventory [14].

2. Predict the spatial distribution of soil erosion in order to prepare maps of soil erodibility factor (K) and soil losses of the Oka River Basin in order to draw up a soil loss map.

3. Determine the potential forestry biomass in the Oka River Basin using a GIS (Geographic Information System).

4. Determine the available biomass while taking environmental factors (erodibility and organic matter in soil) and economic factors (slope of land) into consideration. The terrain slope has been used as an influencing factor for the operations cost due to the difficulties of machinery to take all the material lying on the forest floor [12].

By estimating the amounts of available biomass that could be generated by forestry activity, it would be possible to plan the use of biomass, taking into consideration both economic and environmental aspects in order to determine the optimum location for the installation of an energy production centre using a GIS.

\section{Methodology}

\subsection{Description of the Study Area}

This study was carried out in the province of Biscay, located in the north of Spain (Figure 1a). The study covers the Oka River Basin and includes the Urdaibai estuary, a site of great ecological value. In 1984, it was declared a "Biosphere Reserve" by UNESCO (United Nations Educational Scientific and Cultural Organization). The river basin is located in the northern/central sector of the Province of Bizkaia $\left(43^{\prime} 12^{\prime \prime} \mathrm{N}, 2^{\prime} 33^{\prime \prime} \mathrm{W}\right.$ ) (Figure $1 \mathrm{~b}$ ). With a temperate, very wet climate, its mean annual temperature is $12-14{ }^{\circ} \mathrm{C}$, with precipitations that range between $1200-1800 \mathrm{~mm}$ year ${ }^{-1}$. This river basin covers an area of approximately $178.1 \mathrm{~km}^{2}$, the main basin being $27 \mathrm{~km}$ long and with a perimeter of $68 \mathrm{~km}$.

According to data from the Third National Forest Inventory (NFI3) [14], forestry land covers a surface area of 14,709 ha, representing $66.86 \%$ of the Urdaibai Biosphere Reserve (UBR). $80 \%$ of the forestry mass consists of plantations of $P$. radiata and E. globulus, thus giving rise to the dominant vegetation type [15]. Morphologically, the river basin is oval in shape and has a general N-S orientation. The area is Mesozoic in origin and basically cretaceous, in which two, clearly contrasting sectors can be differentiated:

1. A southern section, head of the river Oka, with deep-v-shaped valleys, the sides of which are dominated by steep slopes.

2. A northern section organised round the Urdaibai estuary, with an average length of $10 \mathrm{~km}$ and a width of between 1 and $2 \mathrm{~km}$, generating a broad, flat valley lying just over sea level, forming a typical landscape of marshes, sandbanks and cultivated areas. 


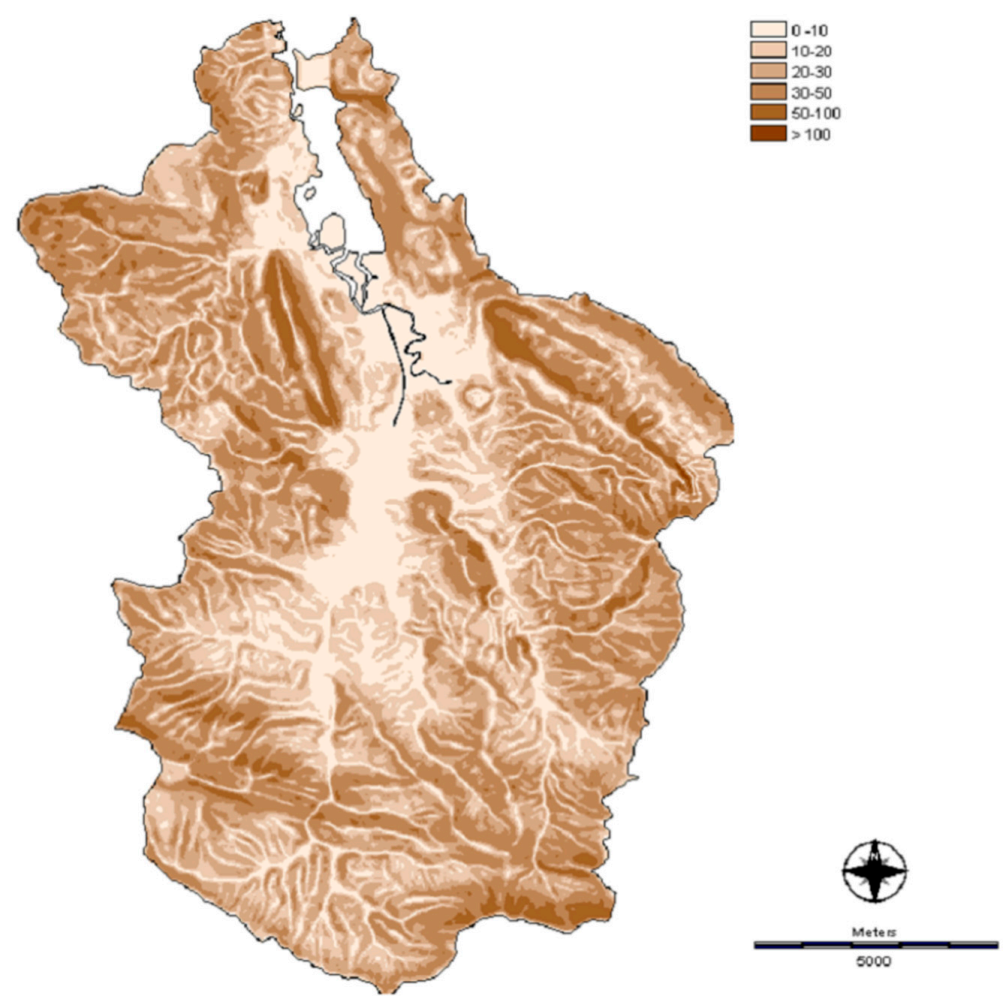

(a)

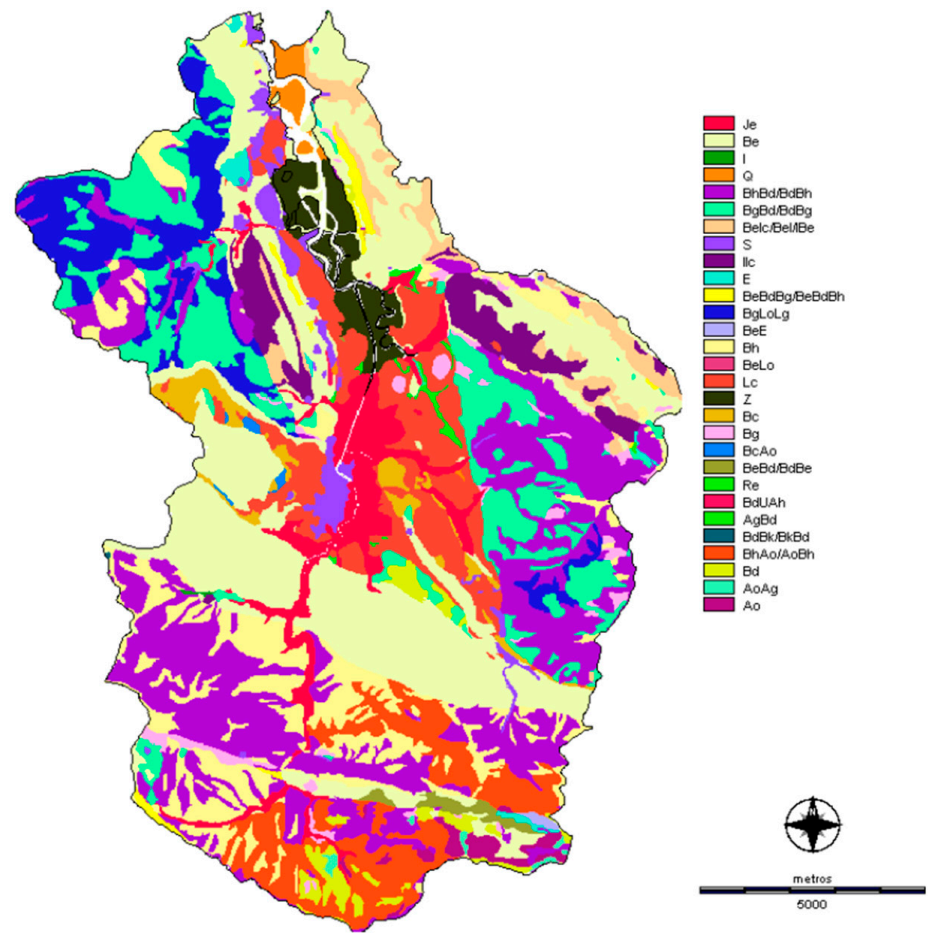

(b)

Figure 2. Maps of the Oka River Basin. (a) slopes map; (b) soils map.

The vegetation map of Urdaibai (Figure 3) shows that about 70\% of the surface area is covered with trees, the dominant species being Pinus radiata D. Don (8764 ha), coinciding with the ecological 
niche of the oak forest [16], followed by Quercus ilex (1555 ha) and Eucalyptus globulus Labill (1321 ha). The rapid growth and the high productivity of $P$. radiata have led it to be, in practice, the dominant forestry species in the Urdaibai Reserve. Forestry activities are performed mainly on private land, as publicly-owned land accounts for less than 500 ha of the Oka River Basin as a whole. Despite their widespread distribution, based on the high market value of by-products from pruning operations, the areas of Quercus have not been considered as a potential source of residual biomass based on the high value added reached by by-products coming from forest operations. Scrub surfaces have not been considered in this study; since the surface they occupy in the territory is rather average (8.6\%), it presents low productivity, and it is a very scattered resource. The study concentrates on the pine and eucalyptus forests made up of $P$. radiata and E. globulus.

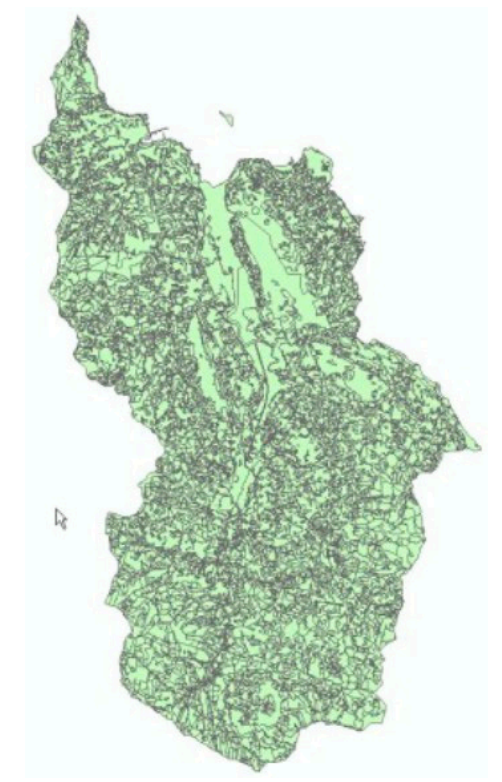

Figure 3. Urdaibai forestry map [16].

\subsection{Validating the Soil Map}

The aim of the first stage of the project was to validate the soil map of the Oka River Basin obtained in the Third National Forest Inventory (NFI3). For this reason, work had focused on gathering and reviewing bibliographical sources and base material (geology, vegetation, orthophotos, etc.). The 1:10,000 forestry map of the Basque Autonomous Community (2004-2005), based on the cartographical standards of the NFI3 in the UTM (Universal Transverse Mercator) reference system (time zone 30) European Datum (1950), was used.

A detailed soil map was drawn up based on information supplied by the 1:25,000 cartography of the Basque Government. Once imported, these were rasterised using a $2 \mathrm{~m}$ pixel size. The coverage was validated based on a laboratory analysis of 345 samples obtained in 115 plots (3 samples per plot) of the study area. The vegetation coverage was also validated with the help of orthophotos and aerial photography. A study was made of the composition of the soil in the area by means of sampling and subsequent laboratory analysis.

The Universal Soil Loss Equation (USLE) was used to estimate the rate of soil erosion in the study area. The USLE was adjusted based on the results obtained in exhaustive field work carried out between 1992 and 1996. During this period, a control was made of the erosion rate, and, for this purpose, 168 experimental plots were installed [17]. The slope map (Figure 2a) and the soils map of the study area (Figure 2b) were drawn up prior to initiating the study. Geologically, the basin comprises eighteen types of soils, cambisols being those that have the greatest extension (60\%), followed by luvisols (8.9\%), acrisols (7.1\%) and fluvisols (5.8\%). 
In order to evaluate the erosion rate of the Oka River Basin, several simulations with GIS tools have been used to analyze the possible soil loss that might be caused by different types of forestry management used in P. radiata plantations. The results obtained by Edeso et al. [18] suggest that, in order to maintain the sustainability of the ecosystem of the area, the intensive soil preparation must be reduced in accordance with the sustainable forestry management proposal. The simplified form of the USLE equation is summarised in the following expression [19]:

$$
\mathrm{A}=\mathrm{R} \cdot \mathrm{K} \cdot \mathrm{S} \cdot \mathrm{L} \cdot \mathrm{C} \cdot \mathrm{P}
$$

where $\mathrm{A}$ is the predicted annual rate of soil loss $\left(\mathrm{Mg} \mathrm{ha}^{-1}\right)$; $\mathrm{R}$ is the rainfall erosivity factor (MJ $\mathrm{mm}$ $\left.\mathrm{ha}^{-1} \mathrm{~h}^{-1}\right), \mathrm{K}$ is the soil erodibility factor $\left(\mathrm{Mg}\right.$ ha $\left.\mathrm{h} \mathrm{ha}^{-1} \mathrm{MJ}^{-1} \mathrm{~mm}^{-1}\right), \mathrm{S}$ is the slope steepness/slope gradient factor, $\mathrm{L}$ is the slope length factor, $\mathrm{C}$ is the crop or cover management factor and conservation or support practice factor $(\mathrm{P})$ is the ratio of the soil loss from land having specified conservation practices to that from land ploughed in a direction parallel to the slope, if all other conditions remain unchanged $[17,18,20]$.

\subsection{Assessment of Annual Rate of Soil Erosion}

Soil loss prediction is necessary for policy makers in land management and ecosystem protection [21]. We set out to simulate the soil loss produced in the Oka River Basin under a number of different conditions. For this purpose, we used the information obtained by direct experimentation and that deriving from the cartographical analysis, as well as from photo-interpretation and the analysis of images obtained through the use of remote sensors.

The erosion rate under the current edaphic and vegetation conditions in the Oka River Basin was simulated, determining the soil loss produced under these circumstances, as well as locating those areas of greatest risk of the production of sediments. To do this, the following documents supplied by the Basque Government were used: Digital Elevation Model (DEM) (1:10,000), soil map (1:25,000); vegetation map $(1: 25,000)$; slopes map obtained from the DEM; and map showing the location of meteorological stations and several additional maps/thematic layers. The rain factor $(R)$ has been determined from the data supplied by 5 observatories situated in the study area, shown in Table 1.

Table 1. Annual rainfall erosivity factor $(\mathrm{R})$ for the five study rain gauge stations.

\begin{tabular}{ccccc}
\hline Station & Altitude & $\mathbf{X}^{*}$ & $\mathbf{Y}^{*}$ & $\mathbf{R}$ \\
\hline Muxika & 20 & 525,325 & $4,793,010$ & 210 \\
Ereño & 502 & 532,950 & $4,799,975$ & 223 \\
Mundaka & 93 & 524,145 & $4,806,115$ & 181 \\
Bermeo & 15 & 522,434 & $4,808,060$ & 191 \\
Amorebieta & 65 & 521,787 & $4,785,950$ & 209 \\
\hline
\end{tabular}

${ }^{*} \mathrm{X}$ and $\mathrm{Y}$ are UTM (Universal Transverse Mercator) coordinates.

Accurate values of $\mathrm{R}$ were obtained in the five stations in which meteorological data are available. These data were implemented through the digitisation of the mean values obtained in other soils with identical characteristics. These values have been extended in a continuous manner over the study area applying geostatistical techniques $[17,18]$.

The $\mathrm{K}$ factor was evaluated based on a random sample made based on the different soils existing in the Oka River Basin (see Section 2.4). This factor is calculated based on a regression equation in accordance with the representative variables of the physical properties of the soil (percentages of organic matter and clay, and the structure and permeability indices).

In some cases, we used the mean values obtained in prior studies of other soils with identical characteristics $[17,18]$. Once the land losses had been obtained in each one of the cells, we re-classified the results by establishing different land categories, shown in Table 2 . 
Table 2. Priority scales for soil erosion.

\begin{tabular}{cc}
\hline Soil Erosion Class & Soil Loss $\left(\mathbf{M g ~ h a}^{\mathbf{- 1}}\right.$ year $^{-\mathbf{1}} \mathbf{)}$ \\
\hline Slight & $(0-5]$ \\
Moderate high & $(5-25]$ \\
Very high & $(25-50]$ \\
Very severe & $(50-100]$ \\
\hline
\end{tabular}

We did not include more groups as the maximum soil loss estimated in previous studies, even when these were subjected to intensive treatments, never exceeded a value of $77 \mathrm{Mg} \mathrm{ha}^{-1}$ year $^{-1}$ [18].

With the data obtained, we set up a database, which, in turn, has been implemented in a GIS. All of the available information was coded in raster format, geo-referencing with a UTM coordinates system and with a space resolution of $2 \times 2 \mathrm{~m}$ in order to determine the erosion rate of the Oka River Basin.

\subsection{Soil Sampling and Analysis}

We selected 115 plots with a minimum surface area of 0.5 ha and length of $60-80 \mathrm{~m}$. These plots were selected so that they covered the main types of soils and the range of slopes of the study area. Soil sampling was carried out from December 2010 to March 2012. At each plot, 9 points were selected at random, in which a surface mineral horizon was taken of the soil $(0-10 \mathrm{~cm})$ through the use of an unaltered soil sampler. With the 9 samples, three samples of equal mass were gathered to build up three composite samples. These were air-dried and sieved at $2 \mathrm{~mm}$ in order to characterise these. At the same time, using a $40 \mathrm{~mm}$ long $\times 55 \mathrm{~mm}$-internal diameter steel cylinder, 3 samples were taken to determine the bulk density. These were dried at $105{ }^{\circ} \mathrm{C}$ to a constant weight. In the air-dried soil samples, the following physiochemical parameters were determined: soil texture (percentage of sand, silt and clay), level of stone content (fractions: $<2 \mathrm{~mm}, 2-50 \mathrm{~mm}$ and $>50 \mathrm{~mm}$ ), bulk density, $\mathrm{pH}$, soil organic carbon (SOC), $\mathrm{N}$ and $\mathrm{S}$, assimilable phosphorous, iron and aluminum, basic cations as well as $\mathrm{Ca}, \mathrm{Mg}, \mathrm{Na}$ and $\mathrm{K}$ and the capacity of the effective cationic exchange (ECEC). The soil texture was determined by means of the Robinson pipette method, according to the international method. The bulk density of each horizon was determined in each test pit following the cylinder methodology [22]. The $\mathrm{pH}$ was determined in $\mathrm{KCl} 0.1 \mathrm{~N}$ with a glass electrode, using a soil: dissolution ratio of 1:2.5 [22]. The concentrations of total $\mathrm{C}, \mathrm{N}$ and $\mathrm{S}$ were determined by means of combustion in a LECO (Corporation St. Joseph, Michigan, MI, USA) automated analyzer.

\subsection{Determining the Potential Residual Forestry Biomass}

The forestry biomass capable of being used for the generation of electrical and/or heat energy is the residual biomass or forestry residue that remains on site following forestry treatments. Residual forestry biomass is considered as that part of the tree not used by the sawmill (branches and leaves or needles). Forest residues are those materials removed in timber-yielding exploitation which are not usually extracted due to the fact that they cannot be converted into by-products. These residues come from the remains left in the forest after forestry, pruning, clearing, and final cutting remains in forest production (cleaning, pruning, tree felling). They can be utilized for energy uses due to their excellent features as fuels.

In general, stand improvements (thinning and clearing) applied to pine forests involve the extraction of a third of the existing trees. With regard to the frequency of the clearing operations, the minimum intensity to be applied to $P$. radiata involves only three clearings, applied at approximately 10-year intervals until logging, which is done at 30 years [23]. Regarding eucalyptus forests, the conventional treatments applied to these plantations are reduced to logging, which is done at 10 years $[23,24]$. Table 3 shows the forestry treatments of the main tree species in the Oka River Basin. 
Table 3. Forest biomass generating silvicultural operations.

\begin{tabular}{cc}
\hline & Stand improvements (thinning and clearing) \\
Two thinnings: 1 st at 10 years, 2 nd at 20 years \\
Action is taken on $1 / 3$ of current trees \\
Logging \\
Logging in 30 years \\
\hline E. globulus & Logging \\
& Logging at 10 years \\
\hline
\end{tabular}

A good approach to estimating the stock of biomass is to use the concept of stratum, as defined in the Third National Forestry Inventory (NFI3). A stratum is formed by grouping the forest surfaces of similar features according to the species present, their states in terms of mass and the fraction of tree cover per area $[12,25,26]$. Specific information concerning such strata is available at the Autonomous Community of the Basque Country (ACBC) Forest Map [27]. Once strata in which P. radiata and E. globulus are the dominant species are selected, the most adequate forest treatments that can be carried out in a ten-year-old horizontal stratum are identified, thus the amounts of residual forest biomass that might be obtained in each stratum considering such treatments are estimated [2].

The methodological process followed for estimating the potential biomass is shown schematically in Figure 4.

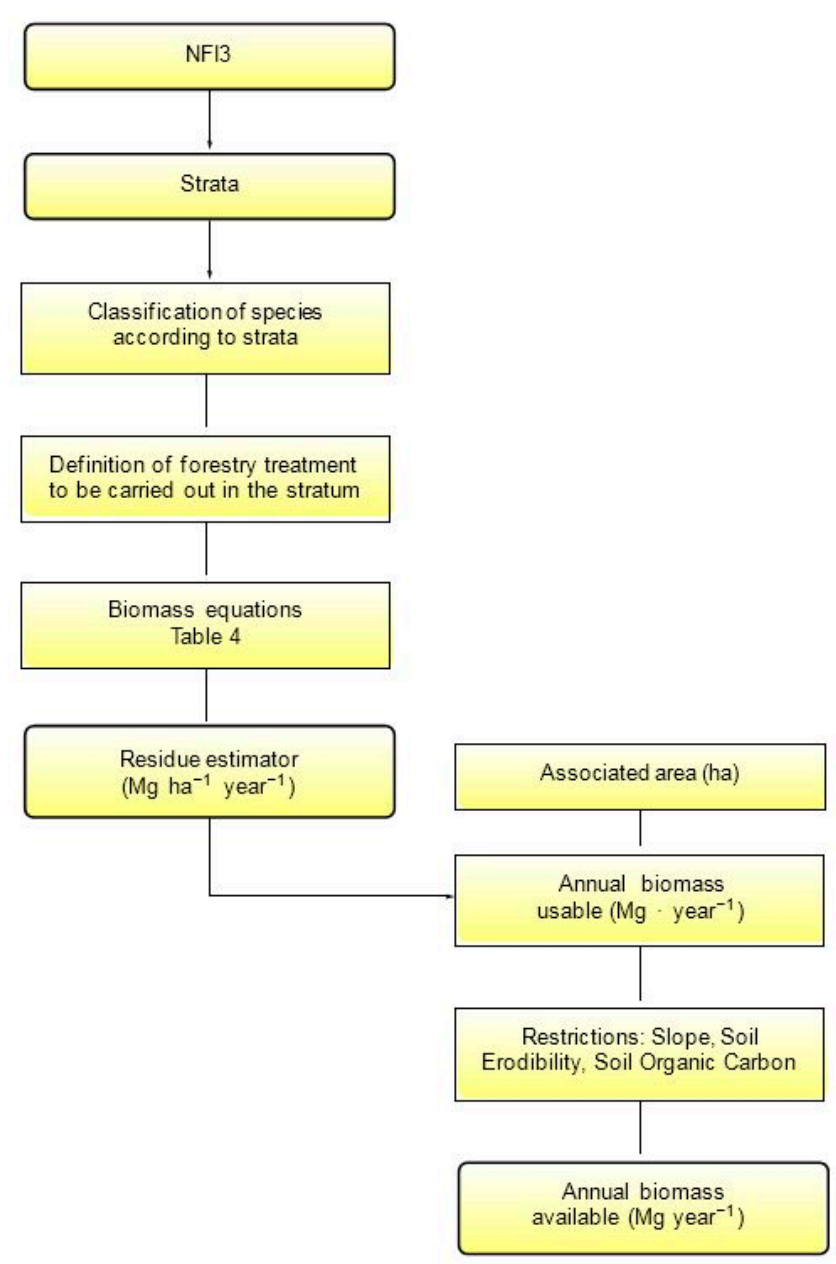

Figure 4. Schematic diagram of the method followed to determine the available residual biomass. 
The methodology used to determine the annual quantity of forest biomass in the area of study consists primarily of determining two factors:

1. The forest residue per unit of surface and time derived from a forest mass $\left(R_{e}, \mathrm{Mg} \mathrm{ha}^{-1} \mathrm{year}^{-1}\right)$ according to the species and forest treatment to which each mass has been subjected to.

2. The surface $(A$, ha) occupied by the forest mass that is going to generate such residue.

The residue estimator $R_{e}$ was calculated using an indirect methodology based on mathematical models that relate the aerial arboreal residual biomass (branches and leaves) with biophysical variables that are easy to measure in forestry inventories such as the normal diameter and sometimes the height [26,28-30].

The most common procedure para la estimación is establishing biomass functions via regression analysis between the biomass of a tree and easily measurable variables such as stem diameter and height. These relations can be expressed mathematically as allometric power models [31,32]. In this project, the methodology followed is based on the biomass fractions introduced by Montero et al. [28]. Such a method develops a logarithmic model, which relates the normal diameter of the tree to the net dry biomass and has the following analytical form:

$$
\ln W=a+b \ln D
$$

where $W$ represents the biomass for each tree (expressed in kg dry mass), $D$ is the diameter at breast height (DBH) or trunk diameter at $1.30 \mathrm{~m}, a$ and $b$ are two specific regression parameters.

This logarithmic equation introduces a bias in the calculations and therefore it is necessary to introduce a correction factor $(\mathrm{CF})$ calculated on the basis of the standard error of the estimation (SEE) $[2,28]$ :

$$
\begin{gathered}
C F=e^{\frac{S E E^{2}}{2}} \\
W=C F \cdot e^{a} \cdot D^{b} .
\end{gathered}
$$

The species-specific allometric equations of [33] for P. radiata and [34] for E. globulus were used to calculate the residual biomass Table 4 . These equations are applied to trees of the diameter at breast height (DBH) of over $7.5 \mathrm{~cm}$.

Table 4. Allometric equations to estimate the potential residual forestry biomass.

\begin{tabular}{cccc}
\hline Species & Equations & $\boldsymbol{R}^{\mathbf{2}}$ & References \\
\hline P. radiata & $\ln W^{*}=-2.47+1.95 \ln D$ & $0.81(p<0.001)$ & {$[33]$} \\
\hline E. globulus & $\frac{W^{*}=0.1785 \times D^{17564}}{2.110}$ & $0.81(p<0.01)$ & {$[34]$} \\
\hline \multicolumn{4}{c}{$W=$ Kg forestry residual dry matter; $D=$ Normal diameter $(\mathrm{cm})}$.
\end{tabular}

Once the estimator of forest residue has been estimated $\left(R e, \mathrm{Mg} \mathrm{ha}^{-1}\right.$ year $\left.^{-1}\right)$ generated by the main forest species in Bizkaia in the strata in which those species are predominant, the following step consists of determining to what surface from the NIF3 can be applied each estimator of residue obtained. As the data used are sampling data, the value of the estimator in a point different from the sampling plot is unknown. To overcome this, Thiesen's polygons from the sampling points are used in order to assign the value of the residue estimator to an influential area of the tree stratum. Using Thiessen polygon analaysis from a layer of points, each Thiessen polygon defines an area of influence around its sample point, so that any location inside the polygon is closer to that point than any of the other sample points. The final result is a division of space in polygons whose name is Voronoi telesation, and in which the limits between polygons are equidistant with respect to their neighbor points. This way of assigning values to the residue estimator to the rest of the non-sampled surface is the most adequate according to several authors $[24,35]$. 
The quantity of annual RFB (residual forestry biomass) susceptible to being useful RFB $\left(\mathrm{Mg} \mathrm{year}^{-1}\right)$, using the surface of the resultant polygons and the tree residue estimators, is estimated as:

$$
\mathrm{RFB}=\sum_{n} A_{n} R_{e_{n i}}
$$

Figure $5 \mathrm{a}, \mathrm{b}$ show the methodological diagram for obtaining the residue estimator Re of the two forestry species analyzed.

The corresponding density of each sampled tree $\left(d, \mathrm{~kg} \mathrm{ha}^{-1}\right)$ is obtained in the calculation of the tree residue estimator. The RFB of tree species are established as the result of the forestry treatments of the forest species, taking into consideration that the rotation period of $P$. radiat $a$ is 30 years and every 10 years it is subjected to a thinning processs of $1 / 3$ of its mass, while the rotation period of E. globulus was considered to be 10 years without prior thinning (Table 5). In this study, the Ciemat methodology was followed [36].

Table 5. Total RFB (Mg year $\left.{ }^{-1}\right)$.

\begin{tabular}{ccc}
\hline Species & Forestry Management & RFB \\
\hline P. radiata & Final felling & $\mathrm{RFB}=\mathrm{RFB}_{\mathrm{T}} / 30$ \\
\cline { 2 - 3 } & Thinning and clearing & $\mathrm{RFB}=\frac{\mathrm{RFB}_{\mathrm{T}}}{3 \times 10}$ \\
\hline E. globulus & Final felling & $\mathrm{RFB}=\mathrm{RFB}_{\mathrm{T}} / 10$ \\
\hline
\end{tabular}

${ }^{*} \mathrm{RFB}_{\mathrm{T}}=$ Total residual forestry biomass obtained throughout the tree rotation period. 


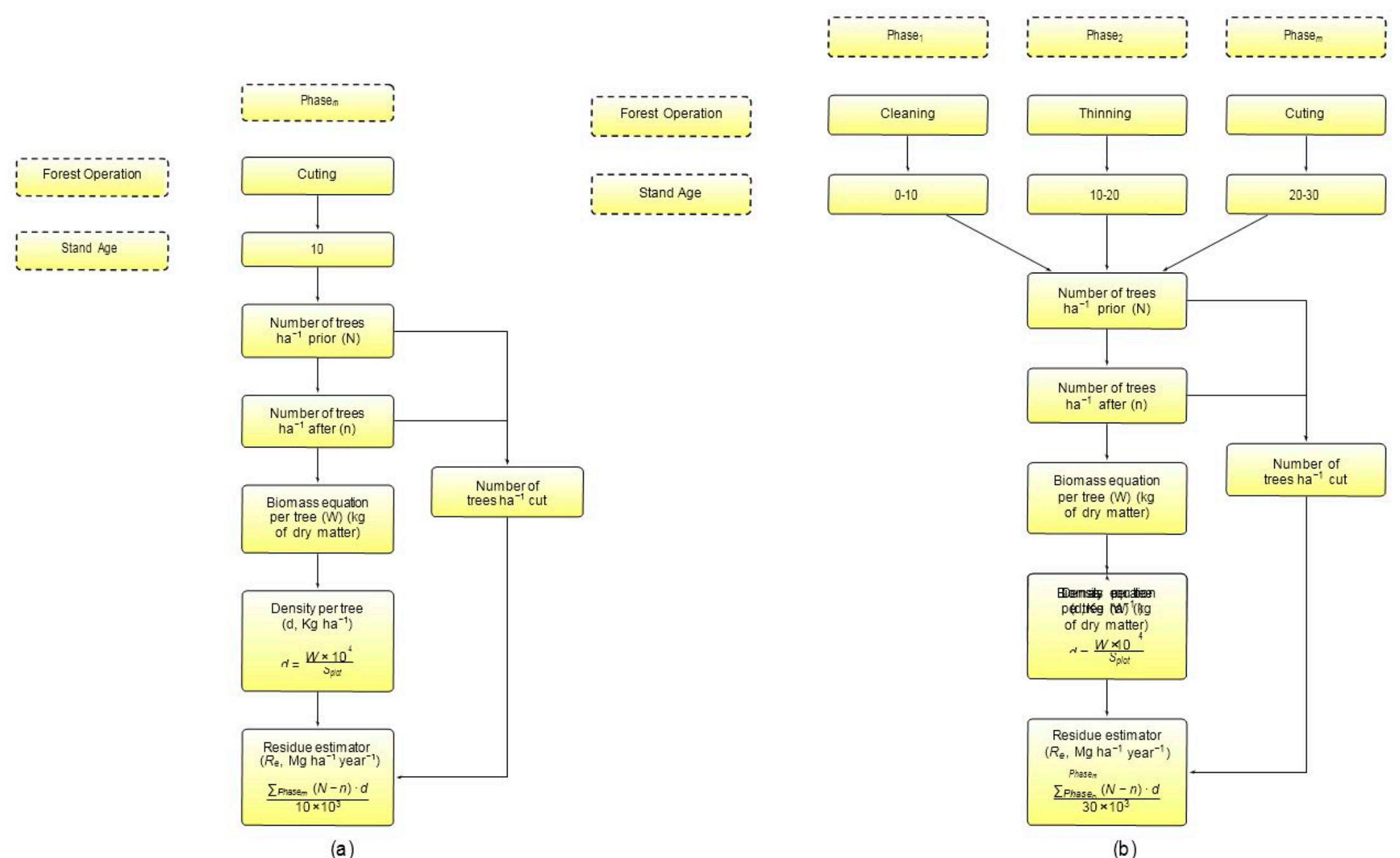

Figure 5. Methodological diagram for determining forestry residue. (a) E. globulus; (b) P. radiate. 


\subsection{Determining the Available Residual Forestry Biomass}

The available residual biomass is found after applying a number of specific restrictions that impede the extraction of biomass (Figure 2a). The restrictions considered in this paper have been determined by the slope of the terrain, the content of organic matter in the upper layer of soil and the erosion, the last of these being measured by the $\mathrm{K}$ factor (susceptibility of the soil to be eroded) of the USLE/MUSLE model. Soil loss and soil erosion patterns may differ with slope gradient, slope aspect, and elevation. In general, increases in slope gradient can produce higher overland flow velocities, and, correspondingly, higher erosion. The slope gradient factor (S) is the ratio of the soil loss from given gradient of the slope to that from land having a 9\% slope [37].

Nevertheless, in previous studies made in other river basins near the study area, soils with erosion in steep slopes were found [17]. For this reason, this study considers both parameters (slope and soil erodibility factor $(\mathrm{K})$ ) separately.

Slope has a direct effect, restricting the type of machinery used to collect and extract biomass. With an increase in slope, the biomass extraction process becomes increasingly expensive and also reduces biomass harvesting productivity $[18,38]$.

With regard to soil loss, the erosion map Figure $6 \mathrm{~b}$ shows that the soils of the Oka River Basin are, in general, free of erosion, of acceptable quality and with mean annual averages of soil loss of under 5 $\mathrm{Mg} \mathrm{ha}^{-1}$ year $^{-1}$.

As shown in the slopes map, $32.69 \%$ of the surface area of the study area has steep slopes of over $50 \%$ and only $16.55 \%$ of the land is flat and corresponds largely to marshes and sand banks. In this study, three slope ranges have been marked out:

1. $<35 \%$, corresponds to the most adequate topographical area for supplying biomass with a lower risk of erosion.

2. $[35,60 \%$, presents moderate suitability with some risk of erosion.

3. $\geq 60 \%$, would correspond to less adequate areas for the extraction of biomass due to their high erosion risk.

Carbon is one of the principal components of soil organic matter (SOM), a key component of soil that plays an important role in many biological, chemical, and physical properties [39,40] Regarding the organic matter of the soil, fertile soils are those that have organic carbon content (dry base) of over $2 \%$, an average of $1-2 \%$ of SOC, and soils very poor in organic matter are those that have a organic carbon content of less than $1 \%$. In previous research, an inversely proportional ratio has been obtained in the SOC and $\mathrm{K}$ factors.

Taking into consideration previous studies carried out in the sampling plots [17,41,42], we have considered soil erodibility factor intervals: for values of $\mathrm{K} \leq 0.015,0.015<\mathrm{K} \leq 0.030,0.030<\mathrm{K}<0.045$ and $K \geq 0.045$ considering respectively low, medium and high erosionability soils. In this way, restricting values have been established for each parameter in order to define the availability of the forestry biomass (Table 6). 


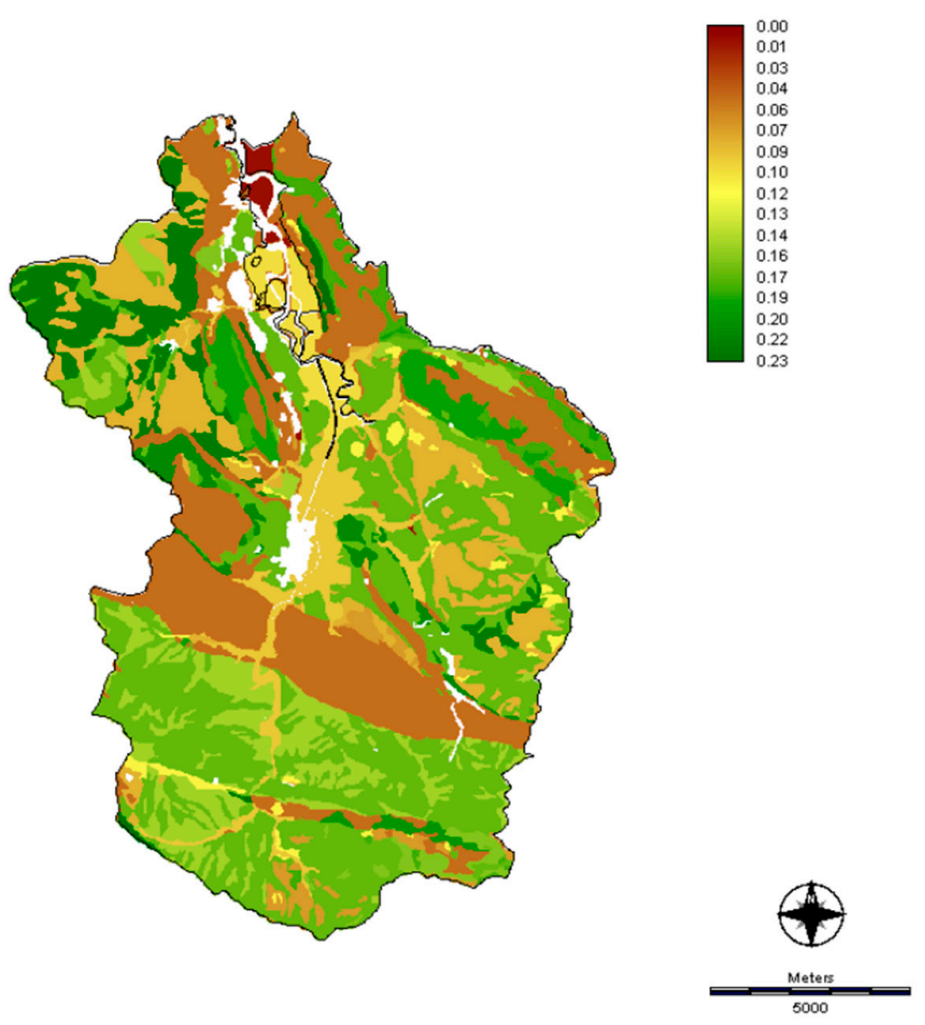

(a)

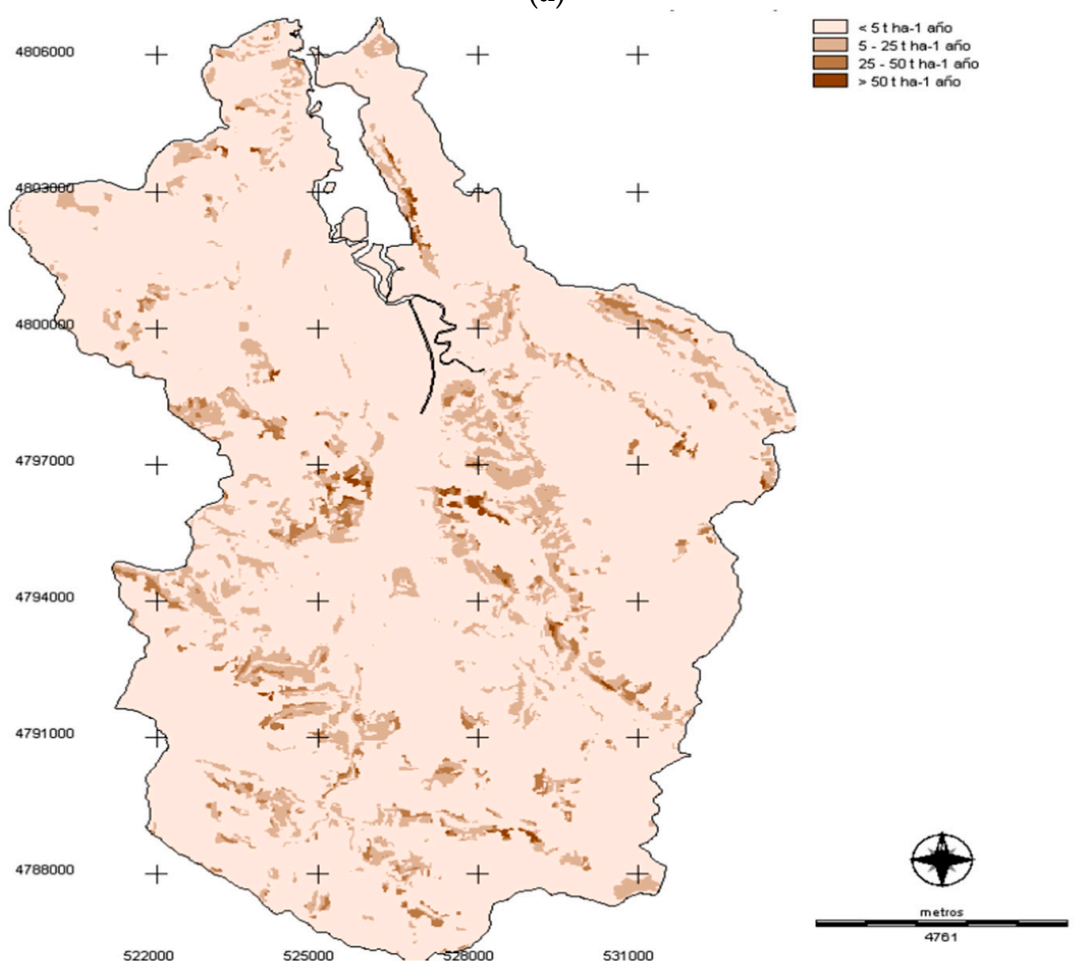

(b)

Figure 6. Maps of the Oka River Basin. (a) soil erodibility map; (b) soil loss map. 
Table 6. Biomass available (\%) in different conditions of slope $(\%)$, soil erodibility factor $(\mathrm{K}, \mathrm{Mg}$ ha $\mathrm{h}$ $\mathrm{ha}^{-1} \mathrm{MJ}^{-1} \mathrm{~mm}^{-1}$ ) and soil organic carbon SOC (\%).

\begin{tabular}{ccccc}
\hline & Slope & $\leq \mathbf{3 5}$ & $\mathbf{3 5 - 6 0}$ & $\geq \mathbf{6 0}$ \\
\hline \multirow{3}{*}{$\mathrm{K}$} & $0-0.15$ & 100 & 80 & 60 \\
& $0.15-0.30$ & 90 & 70 & 50 \\
& $0.30-0.45$ & 0 & 0 & 0 \\
\hline \multirow{3}{*}{ SOC } & $>2$ & 100 & 80 & 60 \\
& $1-2$ & 80 & 50 & 0 \\
& $0-1$ & 0 & 0 & 0 \\
\hline
\end{tabular}

\subsection{Adjusting Predictive Models for Estimating Available Forestry Waste Biomass}

A model is fitted in which the residual forestry biomass (RFB) is estimated as a variable dependent upon predictive variables: slope and erosionability of each plot. In order to study these relationships, linear regression models were used in Equation (6):

$$
y_{j}=\beta_{0}+\sum \beta_{i} x_{i j}+\varepsilon_{j}
$$

where $y_{j}$ is the dependent random variable (in our case, the RFB); $\beta_{0}$ is the linear regression independent coefficient; $\beta_{\mathrm{i}}$ are the predictive variable coefficients, which represent known values of the predictive variables, where $\varepsilon_{\mathrm{j}}$ is the random disturbance (error term). The models were fitted by means of regression, using the ordinary minimum squared method [43]. The fits were evaluated statistically by means of the determination coefficient corrected by the number of parameters $\left(R^{2} \mathrm{aj}\right)$. In order to verify the significance of each one of the fit parameters, an individual contrast was applied with the Student's $t$-test. For the choice of equations, the cases of variance normality and homogeneity were checked [11].

\subsection{Implementing the Method in a GIS}

Geographic Information Systems are useful tools for understanding the geographic context of a wide range of issues pertinent to bioenergy, especially energy demand and biomass supplies. Idrisi Selva and Quantum GIS using the different algorithms of the programme (Interpol and TIN for the interpolations) were used in the present study.

\section{Results}

\subsection{Modelling the (RFB) in Accordance with the Slope Erodibility and Soil Organic Carbon}

Parameter estimates, standard errors of the fitted models according to Equation (7):

$$
\mathrm{RFB}=\beta_{0}+\beta_{1} \times \mathrm{K}+\beta_{2} \times \mathrm{S}+\beta_{3} \times \mathrm{SOC} .
$$

The parameter estimates and goodness of fit statistics of the best linear model obtained for the main stand and canopy variables using the stepwise variables selection method and the NFI3 data as regressors are summarized in Table 7. The behaviour of the model we obtained is good, explaining more than $86 \%$ of the variability observed. The results obtained in the statistical analysis showed that there was a negative correlation between the variables $\mathrm{K}$ and SOC $(r=0,71, p<0.01)$. 
Table 7. Estimated parameters, standard errors of the fitted models.

\begin{tabular}{cccccccc}
\hline $\begin{array}{c}\text { Tested } \\
\text { Model }\end{array}$ & $\begin{array}{c}\text { Dependent } \\
\text { Variable }\end{array}$ & $\begin{array}{c}\text { Independent } \\
\text { Variable }\end{array}$ & $\boldsymbol{R}^{\mathbf{2}}$ aj & $\begin{array}{c}\text { Estimated } \\
\text { Parameter }\end{array}$ & $\begin{array}{c}\text { Standard } \\
\text { Error }\end{array}$ & $\boldsymbol{t}$-Value & $\boldsymbol{p}>|\boldsymbol{t}|$ \\
\hline \multirow{3}{*}{ Equation (7) } & \multirow{2}{*}{$\mathrm{RFB}$} & Intercept & \multirow{2}{*}{$\mathrm{K}$} & 0.033531 & 0.133103 & 108.998 & 0.046 \\
& & $\mathrm{~S}$ & & 3.397875 & 0.012501 & 402.276 & $<0.001$ \\
& & & 0.014747 & 2.004521 & 364.702 & $<0.01$ \\
\hline
\end{tabular}

The fitted equation Equation (7) shows good fit statistics. All the parameters were significant at a confidence level of $95 \%$. In the evaluation of the cases of variance normality and homogeneity of the fitted model, no evidence was found that suggested any non-compliance of the cases. The statistical analysis indicates that there is a relationship between $\mathrm{K}$ and $\mathrm{S}$. The greater the erosion, the lower the amount of SOC.

\subsection{Physical-Chemical Characterisation of Soils}

Tables 8 and 9 show the mean values obtained in the physical-chemical characterisation in 2 of the 115 plots analyzed: A (forest floor soil samples) and B (soil samples subjected to site following felling performed 6 months earlier.) The physical-chemical analysis made of the 115 plots revealed very different erodibility values $(\mathrm{K})$ of the soil before and after felling, e.g., Table 8.

Table 8. Mean values of the physical characteristics of soils.

\begin{tabular}{|c|c|c|c|c|c|c|c|c|c|c|c|c|}
\hline \multirow{2}{*}{$\begin{array}{c}\text { Forestry } \\
\text { Management }\end{array}$} & \multirow{2}{*}{$\begin{array}{l}\text { Depth } \\
\text { (cm) }\end{array}$} & \multirow{2}{*}{ Erodibility K } & \multirow{2}{*}{$\begin{array}{l}\text { Soil Class } \\
\text { FAO }\end{array}$} & \multirow{2}{*}{ Material } & \multirow{2}{*}{$\begin{array}{c}\text { D.a. }{ }^{\ddagger} \\
\left(\mathrm{g} \mathrm{cm}^{-3}\right)\end{array}$} & \multirow{2}{*}{$\begin{array}{l}\text { Depth } \\
(\%)\end{array}$} & \multicolumn{2}{|c|}{ Sand \% } & \multicolumn{2}{|c|}{ Silt $\%$} & \multirow{2}{*}{ Clay (\%) } & \multirow{2}{*}{ Texture } \\
\hline & & & & & & & $\mathrm{Gr}$ & Fin & $\mathrm{Gr}$ & Fin & & \\
\hline$A \S$ & $0-10$ & $<0.02$ & $\begin{array}{c}\text { Alisols } \\
\text { Haplico ALh }\end{array}$ & Argilitas & 1.16 & 18 & 4.3 & 12.2 & 14.4 & 35.8 & 33.2 & $\mathrm{fpl}^{+}$ \\
\hline $\mathrm{B}^{\$}$ & $0-10$ & $(0.15,0.30)$ & $\begin{array}{l}\text { Anthrosols } \\
\text { Arico }\end{array}$ & $\begin{array}{c}\text { Sandstones } \\
\text { and Clays }\end{array}$ & 1.4 & 30 & 12.6 & 30.9 & 13.2 & 18.6 & 24.8 & $\mathrm{f}^{*}$ \\
\hline
\end{tabular}

${ }^{*}$ loamy texture; ${ }^{\dagger}$ silty clay loam; ${ }^{\ddagger}$ bulk density; ${ }^{\S}$ P. radiata forest sawtimber stage; ${ }^{\$}$ forestry management after felling (without subsoiling).

The data obtained exhibited higher apparent density values in soils in which the tree biomass has been taken away after felling and the soil has been prepared for the following rotation compared to soils under plantations. Bulk density increased following site preparation practices. Such is the case of B soils where bulk density was $21 \%$ higher compared to A soils under mature plantation (Table 8 ). The results are in agreement with prior studies made in northern Spain, in which increase in apparent density of up to $1.5 \mathrm{~g} \cdot \mathrm{cm}^{3}$ were found on land from which tree biomass had been removed and in which heavy machinery had been introduced $[18,33]$.

Table 9. Mean values of the chemical parameters of the soils.

\begin{tabular}{|c|c|c|c|c|c|c|c|c|c|c|c|}
\hline \multirow{2}{*}{$\begin{array}{c}\text { Forestry } \\
\text { Management }\end{array}$} & \multirow{2}{*}{$\begin{array}{l}\text { Depth } \\
\text { (cm) }\end{array}$} & \multirow{2}{*}{$\mathrm{pH}$} & SOC * & $\mathbf{N}$ & $\mathrm{Ca}$ & Mg & $\mathrm{Na}$ & $\mathbf{K}$ & Al & ECEC $^{+}$ & \multirow{2}{*}{ Al. Sat. $\ddagger \%$} \\
\hline & & & \multicolumn{2}{|c|}{$\%$} & \multicolumn{6}{|c|}{$\mathrm{cmol}_{\mathrm{c}} \mathrm{kg}^{-1} \%$} & \\
\hline A & $0-10$ & 4.56 & 7.72 & 0.26 & 4.99 & 1.44 & 0.44 & 0.31 & 4.45 & 11.63 & 38.26 \\
\hline B & $0-10$ & 3.96 & 3.10 & 0.12 & 0.27 & 0.21 & 0.15 & 0.12 & 6.28 & 7.03 & 89.33 \\
\hline
\end{tabular}

${ }^{*}$ soil organic carbon; ${ }^{\dagger}$ effective exchange capacity; ${ }^{\ddagger}$ aluminum saturation.

The results obtained from the analysis of the physical-chemical parameters show that the soils of this basin of the Oka River are in general highly acidic (average $\mathrm{pH}$ between 4.1-4.8). Irrespective of the type of soil and the initial geological material, the content of SOC of the surface soil horizons with mature forests is always high, with average carbon contents of between $6.2-7.9 \%$. The results of SOC obtained in all the plots analyzed show high SOC contents, much higher than the $2 \%$ shown within the restrictions (Table 6). In this study, these SOC values were taken as environmental restriction following the recommendations of previous research carried out in the Mediterranean region [12]. In spite of the fact that the Oka River Basin is within the Atlantic zone, in view of the steep slopes, we decided to 
carry out the study with the recommended SOC values, in view of the orography and the steep slopes of the river basin. However, the results show that the SOC of the soils of the basin exhibit very high values and therefore the SOC would not mean in any case a restriction in the extraction of residual forestry biomass for energy use.

Irrespective of the type of soil and the initial geological material, the content of SOC of the surface soil horizons with mature forests is always high, with average carbon contents of between 6.2-7.9\%. This data indicates that these are erosion-free soils, for which very low erosionability factor values have been obtained $(\mathrm{K}<0.02)$ and that the slope of the land does not have a significant effect on the SOC. However, those soils that have been subjected to work done in order to prepare the terrain after the logging suffer a significant drop in the content of SOC (average contents of 3.05-5.45\%) and significant increases in bulk density. This effect increases considerably when highly-mechanised forestry management systems are used and terrain is prepared using deep ploughing.

For this reason, felling and land preparation work make have a serious effect on the soil. It has been found that, for $\mathrm{K}<0.15$, the soil has an adequate texture, with SOC in excess of 5-5.4\%, good permeability and high hydraulic conductivity, indicating that its conditions are adequate for withdrawing RFB for use. As the value of $\mathrm{K}$ increases, the content in SOC decreases. $\mathrm{K}$ values above 0.3 point to unstructured soils (lithosols, anthrosols, etc.) or decapitated soils (lacking surface horizon), and therefore may exhibit low percentages of SOC (between 1-2\%) and different types of textures. In practical terms, there are no soils in the Oka River Basin with such a high level of erosion. The $\mathrm{K}$ values obtained in the river basin are in all cases lower than 0.3 except in a few unrepresentative cases.

Our study indicates that, in general, the soils of the Oka River Basin show low erosion levels. In addition, $63.45 \%$ of the soil analyzed exhibits erosion rates of under $10 \mathrm{Mg} \mathrm{ha}^{-1} \mathrm{year}^{-1}, 25.67 \%$ show erosion rates of $10-20 \mathrm{Mg} \mathrm{ha}^{-1}$ year $^{-1}, 8.61 \%$ show erosion rates of $20-30 \mathrm{Mg} \mathrm{ha}^{-1}$ year $^{-1}$ and $^{-1}$ only $2.27 \%$ of the soil is heavily eroded with soil losses of over $50 \mathrm{Mg} \mathrm{ha}^{-1}$ year $^{-1}$. The last case corresponds to soils subjected to intensive land preparations after felling.

These results confirm the observations made by several members of this research team in soil erosion studies with regard to the drop in SOC associated with the intensity of the soil management following logging. Wet Biomass refers to the humidity of the RFB when this is collected, which is generally estimated at $30 \%$, as it remains in piles for a time in the countryside after felling. As in the case of prior research, in our case, soil samples have been taken some 6 months following felling.

\subsection{Estimating the Potential and Useable Residual Forestry Biomass in the Oka River Basin}

The estimators of the residue obtained for $P$. radiata fluctuate between 0.286 and $0.885 \mathrm{Mg} \mathrm{ha}^{-1}$ year $^{-1}$ of dry matter. With respect to E. globulus, the residue estimators obtained values from 0.346 to $2.156 \mathrm{Mg} \mathrm{ha}^{-1}$ year $^{-1}$ dry matter. Similar studies carried out in other areas of Spain, e.g., [5] estimated 1.3 $\mathrm{Mg} \mathrm{ha}^{-1}$ year $^{-1}$ of wet matter residual biomass in P. radiata in Navarra (Spain), and [24] found values of estimated residual biomass of between 0.68 and $1.41 \mathrm{Mg} \mathrm{ha}^{-1}$ year $^{-1}$ (dry mater) or 0.97 and $2.020 \mathrm{Mg} \mathrm{ha}^{-1}$ year $^{-1}$ (wet matter) or in E. globulus plantations in Huelva (Spain). A humidity of $30 \%$ has been considered, as this is the humidity accepted by a number of different researchers when the residual biomass is gathered for energy valuation [24].

The amount of residual forestry biomass estimated in the Oka River Basin was $7775.32 \mathrm{Mg}_{\text {year }}{ }^{-1}$ (dry mass), of which $6334.12 \mathrm{Mg} \mathrm{year}^{-1}$ (dry mass) correspond to the remains of $P$. radiata and 1441.20 $\mathrm{Mg} \mathrm{year}^{-1}$ (dry mass) to those of E. globulus (Figure 7a).

The amount of residual forestry biomass useable for energy purposes taking into consideration technical and environmental constraints-erodibility $(\mathrm{K})$, slope of the terrain and soil organic carbon (SOC), has been estimated at $4858.23 \mathrm{Mg}$ year $^{-1}$ (dry mass), which corresponds to $6940.33 \mathrm{Mg} \mathrm{year}^{-1}$ (Figure $7 \mathrm{~b}$ ). The results of the study show that the useable residual biomass represents $62.5 \%$ of the available potential residual biomass. The remaining unused forestry waste could offset the soil losses in the most highly eroded horizons in view of the fact that a large part of the nutrients assimilated by the tree are accumulated in the latter's waste or non-timber fraction [33]. 

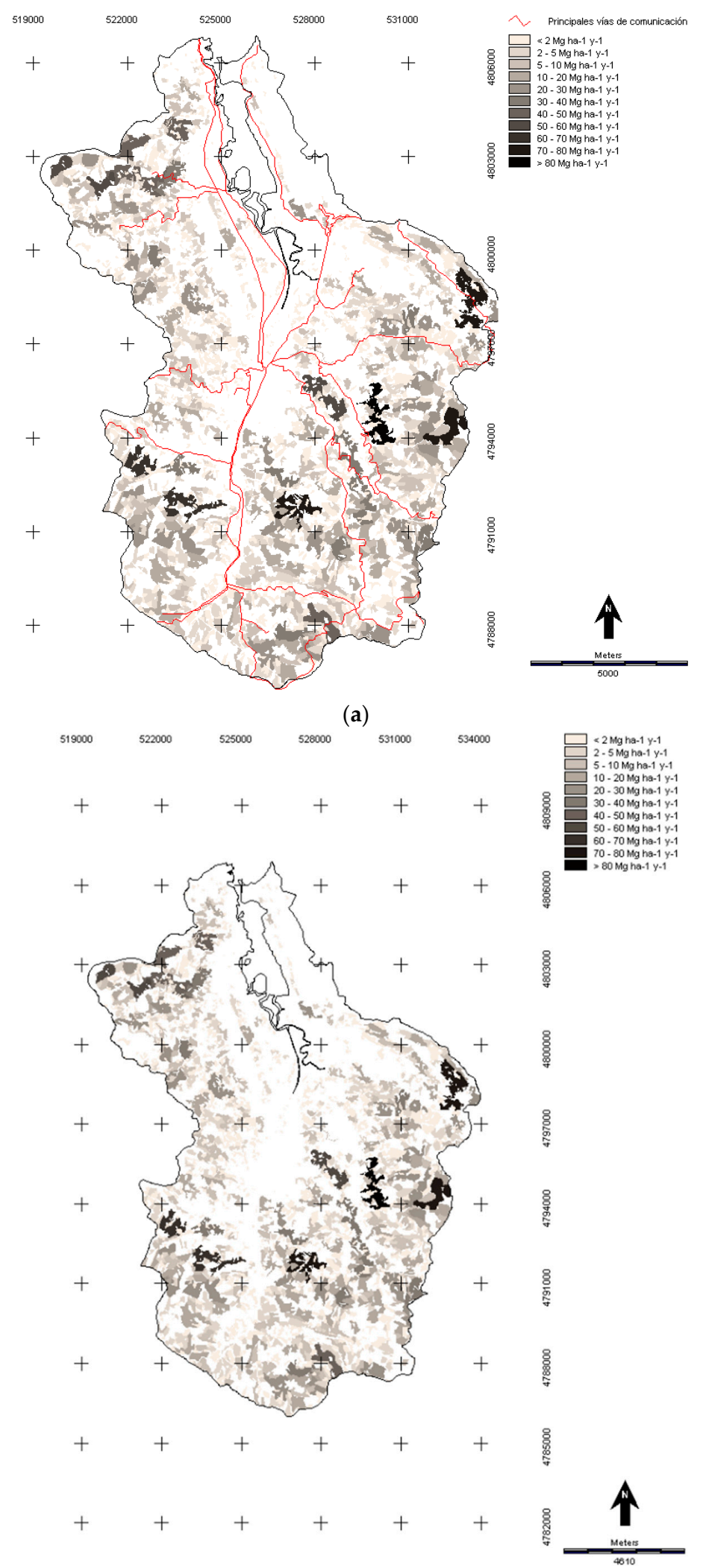

(b)

Figure 7. Residual biomass. (a) usable; (b) available. 


\section{Conclusions}

The results show that the plots with less biomass correspond to those that have been subjected recently to intensive treatments of the land for the next rotation after felling. These areas are the ones that show higher soil loss values. Similar conclusions were obtained in soil studies made in the Arroyo de la Vega River Basin (Madrid) [44].

The forest residues considered in the present study could replace, at least in part, some of the fuels that are currently in use. We believe that, in the Basque Country, the most promising applications are cogeneration in medium-sized power stations and combustion in small and medium-sized plants for heat and steam generation. The specific features of the economy of scale restrict the design of energy plants to those with a minimum production capacity of at least $1 \mathrm{MW}$. This corresponds to a need for $4700 \mathrm{Mg}$ year $^{-1}$ of raw material (dry mass). This value is similar to the annual amount of useable residual biomass estimated in this paper (4858.23 $\mathrm{Mg} \mathrm{year}^{-1}$ ). The use of forestry waste for energy purposes could provide employment and business opportunities in rural communities. An increase in the use of residual forest biomass as a source of energy instead of conventional fossil fuels will represent important environmental advantages and will help member states to meet the targets of EU policies in terms of energy rationalisation.

Information on the amount of available forestry biomass waste, taking sustainability principles into consideration, represents a valuable tool for forestry management, due to its association with soil conservation, spread of pests and fires. Through the harvesting of forestry biomass, a large reduction in forest fires is expected. At this time, forest fires are a source of concern in the study area (of great ecological value and a UNESCO Biosphere Reserve), in view of the enormous potential environmental impact.

Acknowledgments: This work has been supported by the Basque Government and by the Office of Research of the University of the Basque Country grant by Project SAI10/147-SPE10UN90 and by Project NUPV14/11, respectively.

Author Contributions: Esperanza Mateos developed conceptual ideas, designed the study, conducted data analysis in field experiments and wrote the paper. José Miguel Edeso and Leyre Ormaetxea developed conceptual ideas and designed the study.

Conflicts of Interest: The authors declare no conflict of interest.

\section{References}

1. Amichev, B.Y.; Burger, J.A.; Rodriguez, J.A. Carbon sequestration by forests and soils on mined land in the midwestern and Appalachian coalfields of the US. For. Ecol. Manag. 2008, 256, 1949-1959. [CrossRef]

2. Mateos, E.; Garrido, F.; Ormaetxea, L. Assessment of Biomass Energy Potential and Forest Carbon Stocks in Biscay (Spain). Forests 2016, 7, 75. [CrossRef]

3. IDAE. Resumen del Plan de Energías Renovables 2011-2020. Available online: http:/ /www.minetur.gob.es/ energia/es-ES/Novedades/Documents/Resumen_PER_2011-2020.pdf (accessed on 1 November 2016).

4. Cabrera, M.; Vera, A.; Cornejo, J.M.; Ordás, I.; Tolosana, E.; Ambrosio, Y.; Martínez, I.; Vignote, S.; Hotait, N.; Lafarga, A.; et al. Evaluación del Potencial de Energía de la Biomasa. Estudio Técnico PER 2011-2020; Instituto para la Diversificación y Ahorro de la Energía (IDAE): Madrid, Spain, 2011.

5. Domínguez, J. Los Sistemas de Información Geográfica en la Planificación e Integración de Energías Renovables; CIEMAT: Madrid, Spain, 2003.

6. Diaz-Balteiro, L.; Alfranca, O.; Bertomeu, M.; Ezquerro, M.; Giménez, J.C.; González-Pachón, J.; Romero, C. Using quantitative techniques to evaluate and explain the sustainability of forest plantations. Can. J. For. Res. 2016, 46, 1157-1166. [CrossRef]

7. Fleming, R.L.; Leblanc, J.D.; Hazlett, P.W.; Weldon, T.; Irwin, R.; Mossa, D.S. Effects of biomass harvest intensity and soil disturbance on jack pine stand productivity: 15-year results. Can. J. For. Res. 2014, 44, 1566-1574. [CrossRef] 
8. Nadeau Fortin, M.A.; Sirois, L.; St-Laurent, M.H. Extensive forest management contributes to maintain suitable habitat characteristics for the endangered Atlantic-Gaspésie caribou. Can. J. For. Res. 2016, 46, 933-942. [CrossRef]

9. Butnor, J.R.; Johnsen, K.H.; Sanchez, F.G.; Nelson, C.D. Impacts of pine species, stump removal, cultivation, and fertilization on soil properties half a century after planting. Can. J. For. Res. 2012, 42, 675-685. [CrossRef]

10. Cannell, M.G. Forests and the Global Carbon Cycle in the Past, Present and Future; European Forest Institute: Joensuu, Finland, 1995.

11. Fonseca, G.; Alice, G.; Rey, B. Models for biomass estimation in native forest tree plantations and secondary forests in the Costa Rican Caribbean Region. Bosque 2009, 30, 36-47.

12. Esteban, L.; García, R.; Ciria, P.; Carrasco, J. Costs in Spain and Southern EU Countries. Clean Hydrogen-Rich Synthesis Gas Report, Chrisgras Fuels from Biomass; Colección Documentos CIEMAT; CIEMAT: Madrid, Spain, 2009.

13. Carter, M.R. Soil quality for sustainable land management. Agron. J. 2002, 94, 38-47. [CrossRef]

14. Third National Forestry Inventory. Available online: http://www.nasdap.ejgv.euskadi.eus/informacion/ inventarios-forestales/r50--7212/es/ (accessed on 3 June 2016).

15. Rodríguez-Loinaz, G.; Amezaga, I.; San Sebastián, M.; Peña, L.; Onaindia, M. Análisis del paisaje de la reserva de biosfera de Urdaibai. Forum de Sostenibilidad 2007, 1, 59-69.

16. Ibarrondo, M.; González-Amuchastegui, M. Gestión de montes en la reserva de la biosfera de Urdaibai: Una oportunidad perdida. Boletín de la A.G.E. 2008, 46, 329-344.

17. Edeso, J.M.; González, M.J.; Marauri, P.; Merino, A. Determinación de la tasa de erosión hídrica en función del manejo forestal: La cuenca del río santa lucía (Gipuzkoa). Lurralde: Investigación y Espacio 1997, 20, 67-104.

18. Edeso, J.M.; Merino, A.; González, M.J.; Marauri, P. Manejo de explotaciones forestales y pérdida de suelo en zonas de elevada pendiente del País Vasco. Cuaternario y Geomorfología 1998, 12, 105-116.

19. Kirkby, M.; Morgan, R. Erosión de Suelos; Editorial Limusa: Ciudad de México, Mexico, 1894.

20. Marcos, M.; Núñez, M. Biomasa forestal: Fuente energética. Energética XXI 2006, 4, 52.

21. Karamage, F.; Shao, H.; Chen, X.; Ndayisaba, F.; Nahayo, L.; Kayiranga, A.; Omifolaji, J.K.; Liu, T.; Zhang, C. Deforestation Effects on Soil Erosion in the Lake Kivu Basin, D.R. Congo-Rwanda. Forests 2016, 7, 281. [CrossRef]

22. Guitián Ojea, F.; Carballas Fernández, T. Técnicas de Análisis de Suelos. 70 (Monografías de Ciencia Moderna); Editorial Pico Sacro: Madrid, Spain, 1976.

23. Dans del Valle, F.J.; Romero García, A.; Fernández, F.J. Manual de Selvicultura del Pino Radiata en Galicia; Asociación Forestal de Galicia: Galicia, Spain, 1997.

24. Zabalo, A. Modelo de Estimación del Potencial Energético de la Biomasa de Origen Forestal en la Provincia de Huelva. Ph.D. Thesis, Universidad de Huelva, Huelva, Spain, 2006.

25. Mateos, E.; Edeso, F.; Bastarrika, A.; Torre, L. Estimación de la biomasa residual procedente de la gestión forestal en Bizkaia. Lurralde: Investigación y Espacio 2012, 35, 13-30.

26. López-Rodríguez, F.; Pérez Atanet, C.; Blázquez, F.; Ruiz Celma, A. Spatial assessment of the bioenergy potential of forest residues in the western province of Spain, Cáceres. Biomass Bioenergy 2009, 33, 358-366. [CrossRef]

27. GeoEuskadi. Mapa Forestal del País Vasco. Available online: http://www.geo.euskadi.eus/mapa-forestaldel-pais-vasco-ano-2010/s69-geodir/es/ (accessed on 7 February 2017).

28. Montero, G.; Ruiz-Peinado, R.; Muñoz, M. Producción de Biomasa y Fijación de $\mathrm{CO}_{2}$ en los Montes Españoles; Instituto Nacional de Investigación y Tecnología Agraria y Alimentaria (INIA): Madrid, Spain, 2005.

29. Alvarez, J.; Rodriguez Soalleiro, R.; Rojo, A. A management tool for estimating bioenergy production and carbon sequestration in Eucalyptus globulus and eucalyptus nitens grown as short rotation woody crops in north-west Spain. Biomass Bioenergy 2011, 35, 2839-2851.

30. Ruiz-Peinado, R.; Montero, G.; Del Rio, M. Biomass models to estimate carbon stocks for hardwood tree species. For. Syst. 2012, 21, 42-52. [CrossRef]

31. Zianis, D.; Mencuccini, M. On simplifying allometric analyses of forest biomass. For. Ecol. Manag. 2004, 187, 311-332. [CrossRef]

32. Stark, H.; Nothdurft, A.; Bauhus, J. Allometries for Widely Spaced Populus ssp. and Betula ssp. in Nurse Crop Systems. Forests 2013, 4, 1003-1031. [CrossRef] 
33. Merino, A.; Rey, C.; Brañas, J.; Rodriguez, R. Biomasa arbórea y acumulación de nutrientes en plantaciones de Pinus radiata. Investigaciones Agrarias Sistemas y Recursos Forestales 2003, 12, 85-98.

34. Silva, R.; Tavares, M.; Pascoa, F. Residual Biomass of Forest Stands, Pinus pinaster Ait. and Eucalyptus globulus Labill. In Proceedings of the Congreso Forestal Mundial 1991, Paris, France, 17-26 September 1991.

35. Gutiérrez Puebla, J.; Gould, M. SIG: Sistemas de Información Geográfica; Sintesis: Madrid, Spain, 1994.

36. Ciemat. Desarrollo de una Aplicación en Base de Sistema de Información Geográfica (SIG) para la Evaluación de Recursos de Biomasa a través de Internet; Especificaciones Técnicas; Centro de Desarrollo de Energías Renovables: Soria, Spain, 2009.

37. Wischmeier, W.; Smith, D.D. Predicting Rainfall Erosion Losses-A Guide to Conservation Planning; Agriculture Handbook; Department of Agriculture: Washington, DC, USA, 1978.

38. Merino, A.; Fernández, A.; Solla, F.; Edeso, J. Soil changes and tree growth in intensively manager Pinus radiata in northern Spain. For. Ecol. Manag. 2004, 196, 393-404. [CrossRef]

39. James, J.; Harrison, R. The Effect of Harvest on Forest Soil Carbon: A Meta-Analysis. Forests 2016, 7, 308. [CrossRef]

40. Brady, N.; Weil, R. The Nature and Properties of Soils; Macmillan Publ. Co.: New York, NY, USA, 2002; Volume 13, p. 992.

41. Merino, A.; González, M.; Edeso, J.; Marauri, P. Modificación en los Caracteres de los Suelos de la Vertiente Cantábrica del país vasco Producidos por Prácticas Forestales. Available online: http://www.ingeba.org/ lurralde/lurranet/lur18/merino18/merino18.htm (accessed on 10 March 2016).

42. Merino, A.; Edeso, J.; Gonzalez, M.; Marauri, P. Soil properties in a hilly area following different harvesting management practices. For. Ecol. Manag. 1997, 103, 235-246. [CrossRef]

43. SAS-Institute. The SAS System for Windows (Release 8.02); SAS-Institute: Cary, NC, USA, 2016.

44. Casermeiro, M.A.; de la Cruz Caravaca, M.T.; Costa, J.H.; Hernando-Massanet, M.I.; Abril, J.M.; Sánchez, P. El papel de los tomillares (Thymus vulgaris L.) en la protección de la erosión del suelo. Anales de Biología 2002, 24, 81-87.

(C) 2017 by the authors. Licensee MDPI, Basel, Switzerland. This article is an open access article distributed under the terms and conditions of the Creative Commons Attribution (CC BY) license (http:/ / creativecommons.org/licenses/by/4.0/). 